\title{
Habits of Mind Calon Guru Matematika dalam Pemecahan Masalah Matematis
}

\author{
Ahmad Dzulfikar \\ Program Studi Pendidikan Matematika, Universitas Pesantren Tinggi Darul' Ulum \\ e-mail: ahmaddzulfikar@mipa.unipdu.ac.id
}

\begin{abstract}
Habits of mind had the impact toward mathematical problem solving skills, especially for the pre-service teacher who will facilitate the development of their students' mathematical problem solving skills in the future. This qualitative descriptive study aimed to analyze mathematical problem solving habits of mind of the pre-service teacher. 22 undergraduate students were the research subject that was chosen by purposive sampling technique. The research instrument was habits of mind scale, interview guide, and mathematical problem solving test. The study found that level of mathematical problem solving habits of mind of the pre-service teacher was apprentice and practitioner. Based on the indicators, habits of thinking flexibly had the largest frequency of subject who had novice level. Whereas, flexibility in choosing and using strategy determined whether the subject could solve the problem or not. This research hypothesized that this condition was affected by prior mathematical ability. Therefore, future research and development of mathematical problem solving habits of mind of the pre-service teacher were needed.
\end{abstract}

Keywords: habits of mind, mathematical problem solving, pre-service teacher, pedagogical content knowledge, prior mathematical ability

\section{PENDAHULUAN}

Salah satu faktor yang diperlukan dalam pemecahan masalah matematis adalah habits of mind. Habits of mind mendukung mahasiswa untuk lebih berpikir, reflektif, dan kreatif dalam pemecahan masalah(Gordon, 2011; Mahmudi \& Sumarmo, 2015). Keterampilan-keterampilan tersebut menjadi penentu kemampuan pemecahan masalah matematis seseorang.

Habits of mind bertujuan membantu mahasiswa untukmeng adopsi cara matematikawan berpikir dalam menghadapi masalah dan berpikir tentang matematika sebagaimana yang matematikawan lakukan (Lim \& Selden, 2009; Mark, Cuoco, Goldenberg, \& Sword, 2010). Ketika seseorang menghadapi masalah matematis, maka ia perlu untuk memahami masalah, melakukan perencanaan dan memilih serta melaksanakan strategi yang sesuai, menginterpretasi hasil ke masalah awal, dan melalukan looking back. Cara berpikir tersebut merupakan langkah pemecahan masalah yang sangat terkenal yang dikembangkan oleh Polya.

Secara lebih luas habits of mind diperlukan dalam literasi, penalaran, pembuktian, dan pemecahanmasalahmatematis, serta kepercayaan diri dalam pemecahan masalah (Elyousif \& Abdelhamied, 2013; KöSe \& TanişLi, 2014; Li, 2013; Miliyawati, 2014; Seeley, 2014). Selain itu, Perkembangan habits of mind berbanding searah dengan sikap positif dan prestasi matematika (Johnson, 2012). Menjadi tidak mengherankan beberapa negara berusaha memasukkan habits of mind dalam kurikulum pembelajarannya, misalnya Amerika Serikat. Gordon (2016) menyebutkan bahwa Amerika Serikat berusaha memasukkan habits of mind dalam kurikulummatematikanya.

Berdasarkan uraian tersebut, habits of mind menjadi aspek yang penting untuk dimiliki 
calon guru matematika. Infiltrasi habits of mind menjadi suatu keharusan. Selain itu, mengasesmen habits of mindmerupakan bagian esensial dalam pembelajaran (Elyousif \& Abdelhamied, 2013; Gordon, 2016). Hal ini dikarenakan dengan memahami habits of mind mahasiswa maka seorang dosen dapat mengembangkan pembelajaran yang dapat mengakomodasi kebiasaan-kebiasaan berpikir mahasiswa, yang muaranya adalah peningkatan kemampuan pemecahan masalah matematis.

Terkait asesmen habits of mind, Li (2013) menyebutkan bahwa terdapat tempat habits of mind yang berperan penting dalam matematika. Keempatnya adalah habits of mind secara umum, habits of mind yang biasa muncul pada matematika, babits of mind geometri, dan habits of mind aljabar.

Penelitian ini mengkaji partisi dari habits of mind yang biasa muncul dalam matematika, yaitu habits of mind dalam pemecahan masalah matematis. Habits of mind dalam pemecahan masalah matematis dipilih karena pemecahan masalah matematis merupakan salah satu daya matematis dan kemampuan pemecahan masalah matematis merupakan salah satu kemampuan matematis berpikir tingkat tinggi.

Habits of mind dalam pemecahan masalah matematis belum dikaji secara khusus dalam penelitian-penelitian sebelumnya (King, 2013; KöSe \& TanişLi, 2014; Lestari, Kusumah, \& Dewanto, 2016; Salwah, 2014; Sujana, 2015; Syukria, Johar, \& Marwan, 2013). King (2013) mengkaji habits of mind geometri, KöSe \& TanişLi (2014) pada aljabar, dan Lestari, Kusumah, \& Dewanto (2016); Salwah (2014); Sujana (2015); serta Syukria, Johar, \& Marwan(2013) mengkaji babits of mind pada matematika.

Syukria, Johar, \& Marwan (2013) mengkaji habits of mind mahasiswa dengan prestasi baik dalam mata kuliah Teori Graph secara umum dengan menggunakan 15 indikator habits of mind dan menemukan bahwa habits of mind berada pada level kurang, cukup, dan sangat baik. Sementara itu, Johnson (2012) mengkaji habits of mind pada numerasi. Dalam penelitiannya ia menggunakan lima indicator untuk mengidentifikasi babits of mind individu dalam numeracy, yaitucuriousity, respect for evidence, persistence, ownership, dan reflection.

Lloyd (2009) menyebutkan bahwa aktivitas yang mengembangkan kemampuan pemecahan masalah matematis mendukung metacognition, flexibility, dan precision. Oleh karena itu, dalam penelitian ini ketiga habits tersebut menjadi indikator habits of mind dalam pemecahan masalah matematis calon guru matematika. Akan tetapi, peneliti menambahkan tiga indikator, yaitu persisting, managing impulsivity, dan using past knowledge to new situation. Penambahan ketiga indikator dilatarbelakangi karena dalam pemecahan masalah kegigihan, kebiasaan mengatur waktu, tindakan, dan membuat perencanaan, serta penggunaan pengetahuan yang dimiliki dalam situasi baru juga menjadi kebiasaan yang menentukan seseorang menjadi problem solver yang baik. Hal ini didukung oleh Handayani (2015) yang menyatakan bahwa seorang mahasiswa dengan habits of mind yang baik lebih memiliki keterampilan mengatur diri dan metakognisi dalam pemecahan masalah matematis.

Oleh karena babits of mind dalam pemecahan masalah matematis belum dikaji secara spesifik dalam penelitian-penelitian terdahulu, maka penelitian ini bertujuan untuk menganalisis habits of mind calon guru matematika dalam pemecahan masalah matematis. Hal ini dikarenakan walaupun idealnya habits of mind mahasiswa telah banyak berkembang dibanding siswa yang berada pada level pelajar (Lestari et al., 2016; Salwah, 2014). Akan tetapi, untuk memasukkan pengembangan habits of mind dalam pembelajaran matematika bukanlah sesuatu yang mudah (Gordon, 2011). Oleh karena itu, perlu analisis habits of mind calon guru matematika. Calon guru matematika yang memahami habits of mind diharapkan memperhatikan habits of mind siswanya dalam pemecahan masalah ketika mengajar nantinya mereka juga. Muara yang diharapkan adalah meningkatnya kemampuan pemecahan masalah matematis mereka. 


\section{METODE}

Metode deskriptif kualititatif digunakan dalam penelitian ini. Subjek penelitiannini adalah 22 mahasiswa calon guru matematika yang dipilih melalui teknik purposive sampling. Skala habits of mind dalam pemecahan masalah matematis menjadi salah satu instrumen dalam penelitian ini.

Skala babits of mind dalam pemecahan masalah matematis digunakan setelah divalidasi oleh dua orang dosen Pendidikan Matematika Universitas Pesantren Tinggi Darul 'Ulum. Seluruh item, berdasarkan analisis dinyatakan valid dan reliabel. Reliabilitas skala ini adalah 0,772 yang tergolong tinggi.

Skala habits of mind dalam pemecahan masalah matematis dikembangkan berdasarkan adaptasi dari indikator habits of mind yang dikembangkan oleh Costa \& Kallick (2008); Jacobbe \& Millman (2009); dan Johnson (2012). Tes pemecahan masalah matematis dan pedoman wawancara menjadi instrumen pendukung untuk menganalisis habits of mind calon guru matematika dalam pemecahan masalah matematis. Wawancara menjadi teknik pendukung untuk menggali lebih dalam habits of mind dalam pemecahan masalah matematis subjek.

\section{HASIL PENELITIAN}

Penelitian ini bertujuan untuk menganalisis habits of mind mahasiswa calon guru matematika dalam pemecahan masalah matematis. Gambar 1 menunjukkan bahwa secara umum habits of mind dalam pemecahan masalah berada pada level pemula dan pelajar. Dari 22 subjek, hanya sekitar sepertiga yang mencapai level praktisi. Sementara sisanya masih berada pada level pelajar. Berikut ini disajikan deskripsi dari masing-masing indikator berdasar Gambar 1.

\section{Habits of Mind dalam Pemecahan Masalah Matematis}

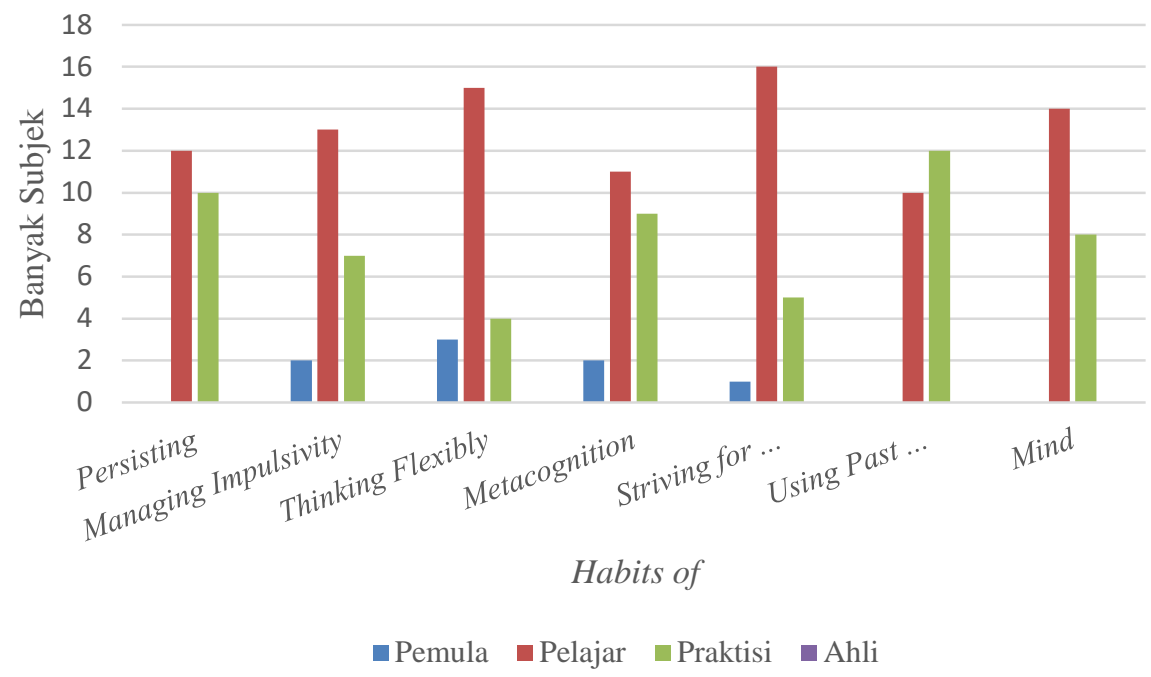

Gambar 1. Habits of mind dalam pemecahan masalah matematis calon guru matematika

Berdasarkan Gambar 1, habits of persisting atau kegigihan dalam menyelesaikan masalah subjek berada pada level pelajar dan praktisi dengan persentase yang hampir berimbang. Hasil tidak jauh berbeda tampak pada kebiasaan subjek dalam menggunakan pengetahuan dan pengalamannya dalam pemecahan masalah matematis.

Gambar 1 juga menunjukkan bahwa persentase responden pada level praktisi semakin menyusut berturut-turut pada habits of metacognition, managing impulsivity, striving for accuracy and presicion, dan thinking flexibly. Pada habits of thinking flexibly hanya 18\% responden yang mencapai level praktisi. Pada keempat habit, subjek mayoritas berada pada level pelajar dengan persentase hampir di atas 50\% pada masing-masing indikator, dan sisanya berada pada level pemula. 
Hasil tersebut menjadi perlu diperhatikan. Hal ini dikarenakan kesadaran guru tentang babits of mind merupakan hal yang sangat penting (Elyousif \& Abdelhamied, 2013; Miliyawati, 2014). Oleh karena itu, seorang guru maupun calon guru matematika seyogyanya memiliki babits of mind yang baik. Hal ini dikarenakan agar mereka dapat memfasilitasi siswanya melalui pembelajaran dalam mengembangkan habits of mind dan kemampuan pemecahan masalah matematis. Untuk dapat menjadi fasilitator habits tersebut, mereka perlu untuk memiliki dan memahami habits of mind yang baik terutama dalam pemecahan masalah. Temuan dari penelitian ini belum menunjukkan hasil ideal tersebut.

\section{DISKUSI}

Pada penelitian ini, habits of mind dalam pemecahan masalah matematis calon guru matematika diukur berdasarkan enam habits. Habits tersebut yaitu habits of persisting, managing impulsivity, thinking flexibly, metacognition, striving for accuracy and precision, dan using past knowledge to new situation. Berikut disajikan pembahasan dari masing-masing habits tersebut.

Habits of persisting, habits ini terkait kegigihan mahasiswa dalam menyelesaikan masalah matematis. Temuan penelitian ini adalah hanya $45 \%$ subjek yang berada pada level praktisi dan sisanya berada pada level pelajar. Subjek pada level pelajar menyatakan bahwa subjek tersebut berusaha untuk menyelesaikan masalah yang diberikan. Akan tetapi, apabila subjek berpendapat bahwa masalah tersebut terlalu sulit untuk diselesaikan, ia menyerah begitu saja. Hal ini terlihat dari beberapa jawaban subjek tersebut yang hanya berusaha menuliskan apa yang diketahui dan ditanyakan dari soal, atau juga membuat sketsa dari permasalahan yang diberikan, tetapi tidak menuliskan pemecahan masalahnya.

Hasil wawancara terhadap subjek dengan habits of persisting pada level praktisi diperoleh informasi bahwa subjek tersebut tetap gigih menyelesaikan masalah-masalah matematis yang diberikan sampai waktu yang diberikan berakhir. Walaupun, subjek tidak yakin apakah penyelesaian yang diperoleh benar atau salah. Pernyataan tersebut sesuai dengan hasil analisis terhadap jawaban tes pemecahan masalah subjek. Dari jawaban subjek, terlihat subjek berusaha untuk menemukan pemecahan masalah yang diberikan, tetapi subjek belum memperoleh jawaban yang tepat.

Habits of managing impulsivity, kebiasaan calon guru matematika mengatur waktu dan tindakannya dalam pemecahan masalah matematis. Kebiasaan ini termasuk kebiasaan membuat rencana serta tenang dalam memikirkan dan memerika cara dan strategi pemecahan masalah.

Penelitian ini menemukan bahwa hanya sepertiga dari keseluruhan subjek yang mencapai level praktisi dan dua kali lipatnya hanya mencapai level pelajar. Sementara itu, sisanya berada pada level pemula.

Hasil analisis terhadap jawaban subjek dengan babits of managing impulsivity level pemula ditemukan bahwa subjek hanya mampu menuliskan informasi yang tersurat dari masalah. Dari hasil wawancara diketahui bahwa subjek tidak mampu memamahi masalah yang diberikan, sehingga mereka tidak mengetahui apa yang diminta dari masalah. Lebih lanjut, hal tersebut mengakibatkan subjek tidak mampu menentukan strategi untuk memecahkan masalah tersebut.

Subjek pada level pelajar menyatakan bahwa mereka kesulitan memahami apa yang diminta dari soal, tetapi mereka tetap berusaha mengerjakan dengan mengikuti langkah Polya. Hal tersebut ditemukan dari jawaban subjek dimana subjek berusaha menuliskan apa yang diketahui dan ditanya dari soal, mencoba merepresentasikannya dalam model matematika dan gambar. Akan tetapi, tidak ada proses yang jelas untuk menyelesaikan masalah tersebut.

Subjek dengan level praktisi melakukan pemecahan masalah yang lebih baik dibandingkan dengan subjek level pelajar. Subjek menuliskan strategi pemecahan masalah yang dibuat, misalkan dengan membuat sketsa. Selain itu, mereka dengan jelas mampu memahami tujuan mereka melakukan itu. Walaupun penyelesaian mereka tidak selalu benar.

Pada habits of thinking flexibly atau kebiasaan seseorang memiliki banyak ide dalam pemecahan masalah matematis, sebanyak $68 \%$ responden berada pada level pelajar, 18\% mencapai level praktisi, dan sisanya berada pada level pemula.

Berdasarkan wawancara subjek dengan babits of thinking flexibly pada level pemula, mereka 
kesulitan dalam mengembangkan ide untuk memecahkan masalah. Ide mereka terbatas pada langsung mengaitkan dengan materi yang telah dipelajari. Akan tetapi, masalah matematis tidak jelas algoritma penyelesaiannya sehingga mereka kesulitan dalam mengembangkan strategi. Hal ini mengakibatkan dilihat dari jawaban mereka belum mampu mengembangkan strategi, misalnya dengan penyederhanaan masalah atau juga dengan mengubah sudut pandang atau strategi lainnya.

Sementara, keluwesan berpikir subjek dengan level pelajar dan praktisi sudah tampak. Dilihat dari jawaban subjek, subjek mampu mengembangkan strategi berbeda ketika mereka melakukan looking back pemecahan masalah dibanding strategi pemecahan masalah pada beberapa masalah yang mampu subjek selesaikan.

Kebiasaan berpikir tentang pemikirannya dalam pemecahan masalah atau babits of metacognition. Kebiasaan ini terkait dengan kebiasaan melakukan refleksi dan memikirkan kembali tentang proses pemecahan masalah matematis. Selain itu, kebiasaan ini terkait dengan refleksi tentang kemungkinan lain dari strategi pemecahan masalah yang dapat digunakan. Berdasarkan hasil penelitian diperoleh bahwa hampir $60 \%$ subjek berada pada level pemula dan pelajar. Subjek dengan level pemula tidak terlalu menyadari pentingnya melakukan metakognisi. Sementara, subjek dengan level pelajar belum terlalu menyadari pentingnya melakukan refleksi terhadap pemikirannya. Mereka hanya fokus pada satu pemikiran dan proses pemikiran dan belum terlalu memperhatikan kemungkinan strategi lain yang mungkin digunakan dalam pemecahan masalah.

Subjek dengan habits of metacognition level praktisi, memiliki keterkaitan dengan babits of thinking flexibly. Dimana mereka berusaha setahap demi setahap melakukan refleksi terhadap ide dan proses pemecahan masalah. Selain itu, mereka berupaya mempertanyakan apakah ada cara lain dalam menyelesaikan masalah yang sama dan mengaplikasikannya dalam mengecek hasil dan prosesnya. Walaupun beberapa masih tergolong strategi pemecahan masalah yang sama.

Dalam pemecahan masalah matematis, ketelitian dan akurasi menjadi salah satu faktor penting agar memperoleh hasil yang tepat. Kebiasaan untuk teliti dan akurat ini disebut sebagai habits of striving for accuracy and precision. Hasil penelitian ini menemukan bahwa hanya sekitar seperlima dari keseluruhan subjek berada pada level praktisi. Sisanya mayoritas pada level pelajar dan sebagian kecil pada level pemula.

Baik subjek dengan level pemula ataupun pelajar, mereka menyatakan bahwa mereka tidak terlalu memperhatikan ketelitian dan presisi dalam pemecahan masalah matematis. Hal ini terlihat dari jawaban subjek yang terlihat ditemukan beberapa salah perhitungan. Sementara itu, subjek dengan level praktisi menyatakan bahwa mereka berusaha untuk teliti dengan meninjau kembali pemikiran dan perhitungan mereka. Hal ini terkait juga dengan habits of managing impulsivity, dimana subjek secara bertahap memerika proses yang mereka lakukan. Kebiasaan menggunakan pengetahuan dan pengalaman yang dimiliki pada situasi baru penting dimiliki ketika menghadapi masalah matematis. Masalah matematis tidak memiliki algoritma yang jelas dalam pemecahannya. Oleh karena itu, pengetahuan sebelumnya dan pengalaman dalam menghadapi masalah serupa terkait dengan berhasil atau tidaknya dalam memecahkan masalah. Kebiasaan menggunakan pengetahuan dan pengalaman ini disebut sebagai habits of using past knowledge to new situation.

Temuan penelitian ini adalah subjek pada habits ini berada pada level pelajar dan praktisi dengan persentase yang hampir sama. Berdasarkan wawancara subjek menyatakan bahwa dalam memecahkan masalah matematis, mereka berusaha mengingat dan mengaitkan pengetahuan yang dimiliki. Namun, karena masalah yang dihadapi adalah sesuatu yang baru dan tidak jelas algoritma penyelesaiannya, maka dari jawaban subjek terkadang mereka salah dalam memilih konsep yang sesuai. Akibatnya beberapa solusi yang diperoleh tidak sesuai.

Secara umum, mayoritas habits of mind mahasiswa calon guru matematika dalam pemecahan masalah matematis masih berada pada level pelajar. Level tersebut tergolong kurang baik dan kurang sesuai bagi calon guru matematika tahun ketiga.

Hasil penelitian ini tidak jauh berbeda dengan temuan King (2013) dan KöSe \& TanişLi (2014). King yang meneliti habits of mind aljabar mahasiswa, menemukan bahwa habits of mind aljabar mahasiswa belum baik. Sementara itu, KöSe\&TanişLi menemukan bahwa calon guru sekolah dasar 
belum memiliki habits of mind geometri sebagaimana yang diharapkan. Akan tetapi, temuan penelitian ini berbeda dengan temuan Syukria, Johar, \& Marwan (2013) yang mengkaji babits of mind secara umum, yang menemukan bahwa habits of mind mahasiswa beragam dari tergolong kurang, cukup, dan sangat baik.

Perbedaan tersebut diduga dipengaruhi oleh kemampuan atau pengetahuan awal yang dimiliki oleh responden. Hal ini dikarenakan perkembangan habits of mind seseorang berbanding lurus dengan prestasinya (Johnson, 2012). Kemampuan atau pengetahuan awal responden penelitian tersebut tergolong baik, hal ini ditunjukkan dari pemilihan responden dengan indeks prestasi kumulatif yang lebih dari tiga yang tergolong memuaskan. Hal ini menjadi keterbatasan penelitian ini. Berdasarkan tes pengetahuan awal yang dilakukan peneliti, ditemukan bahwa pengetahuan awal seluruh subjek penelitian tergolong kurang baik.

Elyousif \& Abdelhamied (2013) dan Gordon (2011) menyebutkan bahwa pembelajaran matematika harus dapat mengembangkan habits of mind peserta didik. Oleh karena itu, idealnya habits of mind mahasiswa telah berkembang. Hal ini dikarenakan pengembangan habits of mind seharusnya telah dilakukan ketika individu berada pada jenjang sekolah pertama, karena mereka berada pada masa transisi dari aritmetika kealjabar (Mark, Cuoco, Goldenberg, \& Sword, 2010). Berdasarkan temuan Lestari, Kusumah, \& Dewanto (2016) dan Salwah (2014) babits of mind siswa dalam matematika berada pada level pelajar. Idealnya habits of mind mahasiswa calon guru matematika telah banyak berkembang. Akan tetapi, banyak faktor yang mempengaruhi perkembangan habits of mind seseorang. Hal ini sejalan dengan pendapat Gordon (2011) yang menyebutkan bahwa untuk memasukkan pengembangan habits of mind dalam pembelajaran matematika bukanlah hal yang mudah.

\section{SIMPULAN}

Berdasarkan uraian tersebut dapat disimpulkan bahwa habits of mind calon guru matematika dalam pemecahan masalah matematis berada pada level pelajar dan praktisi. Banyak mahasiswa dengan level pelajar hampir mencapai dua kali lipat dibanding level praktisi. Hal ini perlu menjadi perhatian karena idealnya habits of mind calon guru matematika telah banyak berkembang dan mencapai level yang lebih baik.

Ditinjau dari masing-masing habits atau indikatornya ditemukan hasil yang tidak jauh berbeda. Bahkan pada habits of thinking flexibly, persentase banyak mahasiswa dengan level pemula paling banyak dibanding habits of mind lainnya. Padahal, dalam pemecahan masalah matematis keluwesan berpikir dalam mengembangkan ide dan strategi mutlak diperlukan. Hal ini diduga salah satunya karena kurangnya kemampuan awal matematis subjek.

Implikasi dari penelitian ini adalah perlunya penelitian lebih lanjut untuk mengkaji pengaruh kemampuan awal matematis terhadap habits of mind seseorang dalam pemecahan masalah matematis. Muara yang diharapkan adalah peningkatan kemampuan pemecahan masalah matematis mahasiswa calon guru matematika.

\section{DAFTAR PUSTAKA}

Costa, A. L., \&Kallick, B. (2008). Learning and leading with habits of mind: 16 essential characteristics for success. (A. L. Costa \& B. Kallick, Eds.). Alexandria, Va: Association for Supervision and Curriculum Development.

Elyousif, Y. A. K. \& Abdelhamied, N. E. (2013). Assessing secondary school teachers' performance in developing habits of mind for the students. International Interdisciplinary Journal of Education, 2(2), 168 180.

Gordon, M. (2011). Mathematical habits of mind: Promoting students' thoughtful considerations. Joumal of Curriculum Studies, 43(4), 457-469. https://doi.org/10.1080/00220272.2011.578664 
Gordon, M. (2016). Habits of Mind-The Heart of the Mathematics Curriculum: Some Instances. In M. Gordon, Enabling Students in Mathematics, 31-45. Cham: Springer International Publishing. https://doi.org/10.1007/978-3-319-25406-7 3

Handayani, A. D. (2015). Mathematical habits of mind: urgensi dan penerapannya dalam pembelajaran matematika. Jurnal Math Educator Nusantara, 1(2), 223-230.

Jacobbe, T \& Millman, R. S. (2009). Mathematical Habits of the Mind for Preservice Teachers. School Science and Mathematics, 109(5), 298-302.

Johnson, R. (2012). Developing Habits of Mind for Numeracy in a Low-Literacy Classroom: a Focus on Attitudes. Minne WiTESOL Journal, 29, 154-161.

King. (2013). Aftermath: Mathematical Habits of Mind. Math Horizons, 20(4), 34-34. https://doi.org/10.4169/mathhorizons.20.4.34

KöSe, N. Y., \&TanişLi, D. (2014). Primary School Teacher Candidates' Geometric Habits of Mind. Educational Sciences: Theory and Practice, 14(3), 1220-1229. https://doi.org/10.12738/estp.2014.3.1864

Lestari, W. D, Kusumah, Y. S \& Dewanto, S. (2016). Improving Student's Habits of Managing Impulsivity Using Project-Assisted Group Investigation. In A. Permanasari, A. Shodikin, \& A. Prisilya (Eds.), Proceeding the 3rd IPCoRe International Postgraduate Colloquium of Research in Education, 205-212. Bandung: FKM SPs UniversitasPendidikan Indonesia.

Li, X. (2013). Conceptualizing and cultivating mathematical practices in school classrooms. Journal of Mathematics Education, 6(1), 60-73.

Lim, K. H \& Selden, A. (2009). Mathematical Habits of Mind. 31st Annual Conference of the North American Chapter of the Internatonal Group for the Psychology of Mathematics Education, 5, 1576-158. Georgia State University, Atlanta, Georgia. https://works.bepress.com/kien lim/13/

Lloyd, C. T. (2009). Discovering Habits of Mind in Mathematics. In A. L. Costa \& B. Kallick (Eds.), Habits of Mind Across The Curriculum: Practical and Creative Strategies for Teachers. Alexandria, Va: Association for Supervision and Curriculum Development.

Mahmudi, A \& Sumarmo, U. (2015). Pengaruh Strategi Mathematical Habits of Mind (MHM) Berbasis Masalah terhadap Kreativitas Siswa. Jurnal Cakrawala Pendidikan, 30(2), 216-229.

Mark, J, Cuoco, A, Goldenberg, E. P, \& Sword, S. (2010). Developing Mathematical Habits of Mind. Mathematics Teaching in Middle School, 15(9), 505-509.

Miliyawati, B. (2014). Urgensistrategi Disposition Habits of Mind Matematis. Infinity Journal, 3(2), 174-188. https://doi.org/10.22460/infinity.v3i2.62

Salwah. (2014). Peningkatan Kemampuan Berpikir Kritis Matematis dan Habits of Striving for Accuracy and Precision (HS AP) melalui Pendekatan Realistic Mathematics Education (RME) Berbasis Gaya Kognitif Siswa Kelas VII : Kuasi Eksperimen pada Siswa SMPN 5 Bandung. Tesis UniversitasPendidikan Indonesia.

Seeley, C. L. (2014). Developing Mathematical Habits of Mind. In Scholastic, 247-259. http://www.mathsolutions.com/documents/Message31 9781935099369 SmarterThanWeThink.p $\underline{\mathrm{df}}$

Sujana, A. (2015). Penerapan Model Pembelajaran PBL untuk Mengembangkan Habits of Mind Mahasiswa. Mendidik: Jurnal Kajian Pendidikan Dan Pengajaran, 1(2), 85-93. 
Syukria, A, Johar. R., \& Marwan. (2013). Kemampuan Komunikasi Matematis dan Habits of Mind Mahasiswa pada Materi Lintasan Terpendek Menggunakan Algoritma Floydwarshall. Jurnal Peluang, 1(2). http://www.jurnal.unsyiah.ac.id/p 